\title{
First record of a chalicothere from the Miocene of Myanmar
}

Olivier Chavasseau, Yaowalak Chaimanee, Pauline Coster, Edouard-Georges Emonet, Aung Naing Soe, Aung Aung Kyaw, Aye Maung, Mana Rugbumrung, Hla Shwe, and Jean-Jacques Jaeger Acta Palaeontologica Polonica 55 (1), 2010: 13-22 doi: http://dx.doi.org/10.4202/app.2009.0033

Here we describe the first record of a chalicothere from the Miocene of Myanmar. The chalicothere, documented by a partial mandible, was unearthed from the lower portion of the Irrawaddy Formation in the region of Magway, Central Myanmar. The Burmese material belongs to an early late Miocene fauna which recently yielded hominoid remains attributed to Khoratpithecus. The specimen, which is attributed to a chalicotheriine, does not reliably match with any described Miocene Eurasian species of this subfamily, suggesting the possibility it belongs to a new taxon. The discovery of a chalicotheriine in the surroundings of Magway contributes to the hypothesis that closed habitats were an important component of the paleoenvironment of Khoratpithecus.

Key words: Mammalia, Chalicotheriidae, Chalicotheriinae, Khoratpithecus, paleoenvironment, Miocene, Myanmar.

Olivier Chavasseau [olivier.chavasseau@univ-montp2.fr], Department of Mineral Resources, Paleontology section, Bureau of Geological Survey, Rama 6 road, Bangkok 10400, Thailand; Institut International de Paléoprimatologie et de Paléontologie Humaine: Evolution et Paléoenvironnements, UMR CNRS 6046 Université de Poitiers, 40 Avenue du Recteur Pineau, 86022 Poitiers, France; Yaowalak Chaimanee [yaowalak@dmr.go.th] and Mana Rugbumrung, Department of Mineral Resources, Paleontology section, Bureau of Geological Survey, Rama 6 road, Bangkok 10400, Thailand; Pauline Coster[pauline.coster@univ-poitiers.fr], Edouard-Georges

Emonet[edouard.georges.emonet@univ-poitiers.fr], and Jean-Jacques Jaeger[jean-jacques.jaeger@univ-poitiers.fr], Institut International de Paléoprimatologie et de Paléontologie Humaine : Evolution et Paléoenvironnements, UMR CNRS 6046 Université de Poitiers, 40 Avenue du Recteur Pineau, 86022 Poitiers, France; Aung Naing Soe[ansoemyanmar@gmail.com], Department of Geology, Dagon University, PO 11422 Yangon, Myanmar; Aung Aung Kyaw, Aye Maung, and Hla Shwe, Department of Archaeology, National Museum and Library, Mandalay, Myanmar. 
This is an open-access article distributed under the terms of the Creative Commons

Attribution License (for details please see creativecommons.org), which permits unrestricted use, distribution, and reproduction in any medium, provided the original author and source are credited.

FoF 